\title{
Caracterização química e extração de ferro de resíduo de mineração por lixiviação ácida
}

\section{Leonardo M. Menedez, Guilherme P. Campos, Heloise O. Pastore.}

\section{Resumo}

Caracterizar a lama de mineração, ou rejeito de mineração, é o primeiro passo para conhecer os desafios que esse material apresenta, visando o desenvolvimento de processos para diminuir sua toxicidade e reutilizar os elementos ali encontrados. Neste trabalho realizou-se um estudo sobre as características de um resíduo de mineração (lama vermelha Alcoa) buscando-se a melhor condição de extração do ferro, principal componente metálico, por meio de lixivação em meio ácido, variando a concentração de ácido sulfúrico e tempo de reação. A concentração total de ferro foi quantificada pelo método de complexação com 1,10-o-fenantrolina.

\section{Palavras-chave:}

Rejeito de mineração, ferro, lixiviação.

\section{Introdução}

Rejeitos de mineração, ou lama de mineração, constituem um problema ambiental e atualmente vem sendo destaque mundial devido a catástrofes ambientais, como o rompimento da barragem de Mariana e Brumadinho em Minas Gerais. A determinação dos constituintes destes rejeitos é importante para que eles possam ser reaproveitados em outros processos. ${ }^{1} \mathrm{Um}$ exemplo estudado nesse projeto é a extração e reuso do ferro, componente majoritário em um resíduo de mineração (Alcoa). O interesse neste elemento se deve à possibilidade de imobilização em zeólitos por troca iônica no preparo de catalisadores para reações foto-Fenton.

\section{Resultados e Discussão}

A determinação do teor de umidade na lama foi realizada pela perda de massa na secagem de uma massa conhecida da lama em estufa a $105^{\circ} \mathrm{C}$ por $24 \mathrm{~h}$. O teor de umidade da lama é de $(48,98 \pm 00,19) \%$.

Para a determinação de orgânicos, realizou-se uma análise termogravimétrica (TG) (Figura 1). É possível observar a perda de água em aproximadamente $100^{\circ} \mathrm{C}$, assim como a de orgânicos na faixa de $200^{\circ}$ a $400^{\circ} \mathrm{C}$. Na faixa de $600^{\circ} \mathrm{C}$ a $700^{\circ} \mathrm{C}$ há perda considerável de massa devido ao fenômeno de desidroxilação dos minerais ali existentes. A análise foi realizada em atmosfera inerte e oxidante. Embora o teor de orgânicos seja de $7,7 \%$ da massa total, não foi observada mudança do perfil termogravimétrico.

$\mathrm{Na}$ análise por Fluorescência de Raios $X$, foi possível determinar a composição elementar da lama seca. As concentrações dos três principais componentes podem ser encontrados na Tabela 1.

Tabela 1. Principais elementos encontrados na lama.

\begin{tabular}{|c|c|c|}
\hline Elemento & Média \% & Desvio\% \\
\hline Ferro & 29,99 & 0,25 \\
\hline Silício & 10,31 & 0,54 \\
\hline Alumínio & 8,61 & 0,11 \\
\hline
\end{tabular}

É de interesse também extrair o componente mais abundante da lama para sua reutilização em outras formas. O ferro pode ser extraído por lixiviação ácida, utilizando-se ácido sulfúrico concentrado.

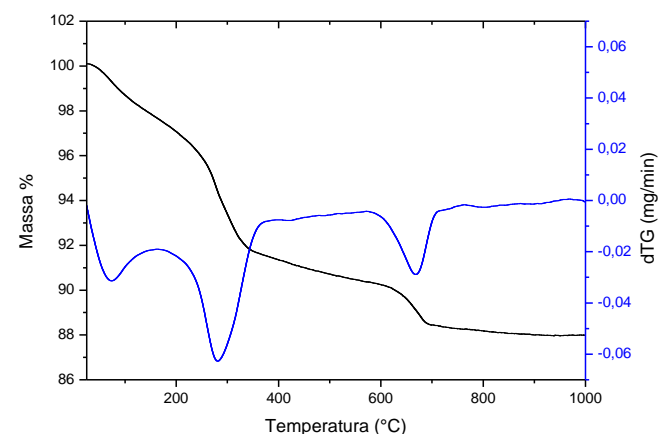

Figura 1. Gráfico do ensaio de termogravimetria e sua $1^{\circ}$ derivada.

Analisou-se a forma como diferentes concentrações de ácido e diferentes tempos de extração influenciariam na concentração total de Fe extraído (Figura 2). Para uma massa de $2 \mathrm{~g}$ de lama, extraiu-se uma média de 84,6 ppm de ferro com $0,3 \mathrm{~mL}$ de $\mathrm{H}_{2} \mathrm{SO}_{4}$. O método de determinação utilizado foi a leitura do complexo colorido ferro o-fenantrolina por espectroscopia UV-VIS.

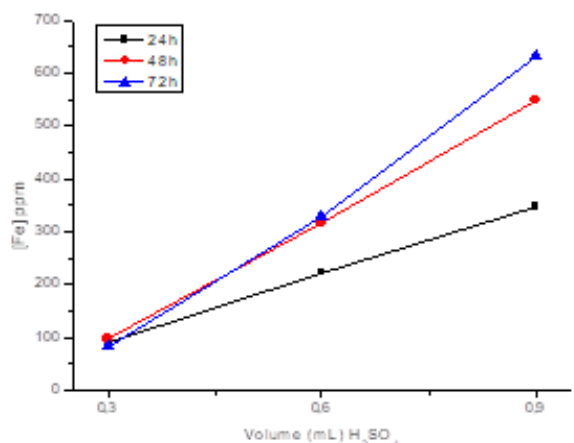

Figura 2. Perfil de extração em diferentes concentrações e tempos de reação com ácido sulfúrico.

\section{Conclusões}

A lama analisada possui teor de umidade de $(48,98$ $\pm 00,19) \%, 7,7 \%$ de matéria orgânica e seu principal componente metálico é o ferro com $(29,99 \pm 00,19) \%$ que pode ser extraído com ácido sulfúrico. O tempo de reação não influencia na extração do ferro quando usada a mesma concentração de ácido. Com o aumento de concentração e tempo de reação, há o aumento da extração de ferro. 